Pobrane z czasopisma Annales $\mathrm{H}$ - Oeconomia http://oeconomia.annales.umcs.pl Data: 26/04/2023 15:03:53

DOI:10.17951/h.2018.52.6.7-23

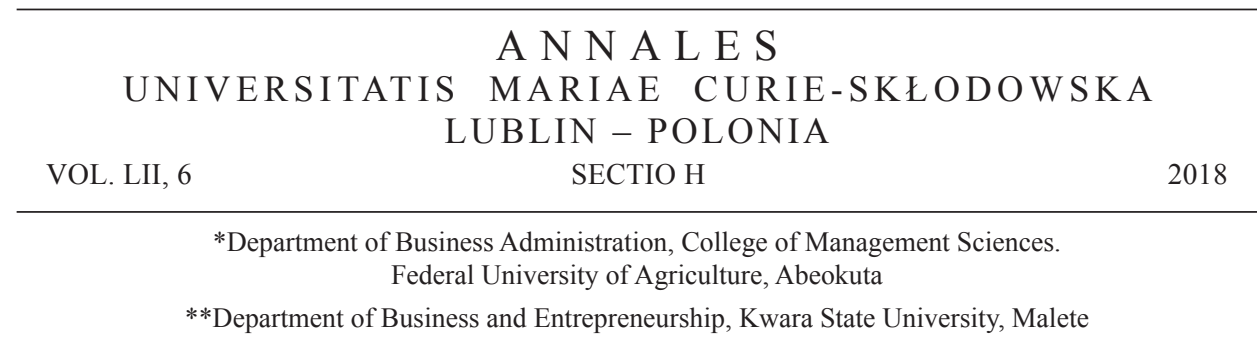

AKINBOLA OLUFEMI AMOS*

ORCID ID: https://orcid.org/0000-0001-7916-4136

akinbolaoa@funaab.edu.ng

EKPUDU JONATHAN EHIMEN*

ORCID ID: https://orcid.org/0000-0003-3032-6936

ekpuduje@funaab.edu.ng

OJEAGA PAUL I.*

ORCID ID: https://orcid.org/0000-0001-9190-3018

ojeagapi@funaab.edu.ng

AKINBOLA OMOLOLA SARIAT**

ORCID ID: https://orcid.org/0000-0001-7021-8986

omololakinbola@gmail.com

\title{
Comparative Study of Research Project Supervision on the Performance of Graduating Business Students in Nigerian Universities
}

Analiza porównawcza nadzoru nad projektem badawczym w zakresie osiągnięć studentów biznesu na uniwersytetach nigeryjskich

Keywords: project supervision; motivational and inhibiting factors; research capacity; graduating performance

Słowa kluczowe: nadzór nad projektem; czynniki motywacyjne i hamujące; możliwości badawcze; końcowe osiągnięcie 


\section{Introduction}

Completing a research project has become an accepted part of learning in universities, as a consequence of the widely recognized benefits of the research process for student learning. A research project offers students the chance to undertake a piece of research in an area of interest to them and pursue it through to completion [Dundalk Institute of Technology, 2011]. Wisker [2005] states that "engaging in research in any subject consists of problematising whatever is given, putting question into action and learning how to develop an evidence base for knowledge claims and contribution". Research allows students to apply concepts and knowledge acquired in their studies through the critical evaluation of relevant theory and research findings, whilst enhancing their research skills through the scope and depth of their inquiry. Research also provides students with opportunities to demonstrate advanced levels of information sourcing, summarizing and synthesizing, along with a high level of composition and structure in the overall presentation of the completed study [Dundalk Institute of Technology, 2011].

A research project is a core and critical element at degree level in the selected universities and, as such, the supervision of a student's research project is by no means a small task for a supervisor. Supervisors have different research backgrounds, expertise and experience [Pearce, 2005]. Some supervisors prefer the supervision of qualitative research, while others prefer supervising quantitative research. In this vein, students' performance is one of the major goals of these universities and it plays an important role in producing the best quality graduates who will become great leaders and manpower for the country's economic and social development [Ali et al., 2009].

\section{Statement of research problems}

In Nigerian universities, a research project is compulsory for the completion of degree programmes in all the faculties or colleges. Students are expected to conduct research to consummate their degree requirements. In the same vein, evidence abounds that graduating students are posed with difficulties in writing original and quality research projects. Some of the difficulties encountered by graduating students in Nigeria universities include lack of time; lack of library resources; ineffectiveness of the project supervisor; inability to carry out their responsibility as a research student; lack of cordial relationship between supervisee and supervisor; imposition of research topic on supervisee; lack of motivational factors and lack of Internet services, to mention just a few of the challenges.

In conjunction, supervisors are faced with difficulties in supervising the research projects of supervisees. Some of these difficulties include the supervisees' inability to craft researchable topics; lack of supervisees' commitment and their negligence, the inability of supervisees to develop a research proposal; a lack of motivational factors; and the inability of supervisees to review the literature, to mention just a few. 
In light of the above, these difficulties could be regarded as factors inhibiting graduating students from writing a high quality and original research project within the time frame as well as preventing the supervisors from ensuring effective and efficient supervision. These inhibiting factors can also affect the performance of the graduating students and also affect the supervisors in terms of the kind of students they produce.

Research authorities such as Bell [2000], Sidhu [2001], Pearce [2005], Anderson et al. [2006], Tichaona and Onias [2011] also made significant contributions to corroborate the aforementioned difficulties encountered by the supervisees and supervisors. Therefore, this research sets out to investigate the comparative investigation of the effects of research project supervision on student graduating performance in the selected universities in Nigeria, in order to assess the following questions and hypotheses: What is the relationship between research project motivational factors and student writing and research capacity? How have inhibiting factors in project writing correlated with student exposure to research? Finally, is there any relationship between the inhibiting factors in project writing, and student writing and research capacity?

\section{Research hypotheses}

H1: There is no relationship between research project motivational factors and student writing and research capacity.

$\mathrm{H} 2$ : Inhibiting factors in project writing do not correlate with student exposure to research.

H3: The relationship between inhibiting factors in project writing, and student writing and research capacity is insignificant.

\section{Concept of research supervision}

Project supervision can be viewed from different perspectives, which include: construction supervision, clinical supervision, research supervision and social work supervision. For the purpose of this study, research supervision is examined. Narayana [2009] viewed research supervision as a complex process and stated that extensive attention and discussion must be engaged to achieve quality research work, as it is an integral part of higher education.

\section{The link between project supervision, writing and defence}

The area of research supervision, writing and defence appears to have been given little attention by researchers, as observed by the sparse literature on the subject, despite the fact that there are problems in project supervision, writing and defence that 
include long completion times, high dropout rates and a failure to successfully defend the research project. As already seen, Lee [2007] highlighted that the supervision of research project, writing and defence should be given greater attention, because the quality of the research project suggests the kind of supervision and writing that was done and the quality of suggestions for improvement made during defence. Most supervisors are likely to supervise students the same way they themselves were supervised, and thus prolong an inflexible tradition of project supervision. Such practices deny and ignore the fact that project supervision requires resourcefulness, expert coaching, facilitative interaction and mentoring, given the many difficulties students face in the area of their study.

Grant [2005] considered that some of the difficulties in project supervision emanate from differences among supervisors, mainly as a function of, among other things, their different theoretical orientations or supervision practices/models to which they subscribe. Lee [2007] suggested a common conceptual approach to the supervision of a research project, which acts as a broad guideline for project supervisors. In conclusion, many factors can contribute to the inability of students to complete their research project within stipulated time and one of the most important factors contributing to this is the kind of supervision they receive. Moreover, when studying the graduating students experience of supervision, there is a need to consider all other aspects. Effective supervision of the research student is recognized as an essential factor in the latter successful completion of the degree [Frischer, Larsson, 2000; Hunter et al., 2006]. Therefore, as far as the supervision is concerned, it is part of the mechanics of ensuring that the students make good progress towards completion.

\section{The concept of student graduating performance}

The research student is the main person responsible for his or her research degree and, as such, should take the responsibility for managing his or her own learning and getting a degree. Also, it is agreed that the student is responsible for an original contribution to the work and developing a mature, critical knowledge of the work area and its context. The responsibility for completing a degree within a reasonable length of time clearly depends on both the student and the supervisor.

Student graduating performance, according to the Cambridge University Reporter [2003], is characterized by performance in tests, in coursework and by performance in examinations of undergraduate students. There are some factors that affect student graduating performance, which include quality of supervision, students' grades/ marks, self-motivation of students, university facilities, management of university, quality of lecturers/supervisors, age of student, gender, faculty of study, father/ guardian economic status, learning preferences, entry qualification of students, daily study hours, etc. [Ali et al., 2013]. This study considers the quality of supervision as the factor affecting student graduating performance. 


\section{Theoretical inference}

Supervisors have a key responsibility to supervise and manage supervisees. There are theories on motivation that have become widely popular and were considered in this study. The theories adopted in this study include theory X and theory Y, which were propounded by Douglas McGregor [1960], theory Z propounded by Williams and Allan [1985] and Two-Factor Theory, propounded by Herzberg [1964] and re-modified in the works of Vergara [2000] and Jeremy [2014]. In addition, the stated theories address both the supervisees and supervisors, because motivation has an impact on supervisees in writing a quality and original research project which in turn has an impact on their academic performance. Furthermore, it enables the supervisors to be active and effective in supervision.

\section{Inference to Two-Factor Theory}

The Two-Factor theory is also known as Herzberg's motivation-hygiene theory and dual-factor theory. This theory mainly discusses the motivation factors and hygiene factors. The motivation factors are the factors that concern job content and lead to job satisfaction, which include growth, work itself, responsibility, achievement, advancement and recognition. When these factors are not present on the job, supervisors/supervisees do not tend to be dissatisfied - they are simply not satisfied. Supervisors/supervisees who are not satisfied do not tend to restrict productivity; they just do not get involved in their job or put extra effort into doing a good job. Supervisors/supervisees who are satisfied give that extra effort and productivity increases. The hygiene factors, on the other hand, are the factors that concern job context and lead to job dissatisfaction, and they include company policies and administration, supervision, interpersonal relations, status, working conditions, security and salary. When these factors are considered good or acceptable, supervisors/supervisees do not tend to become satisfied, they simply become not dissatisfied. Productivity is not restricted - it is just held at an acceptable level. When supervisors/supervisees become dissatisfied with any of these factors, they tend to restrict output.

\section{Empirical studies}

Doreen and Scott [2006] conducted research on the impact of undergraduate research on academic performance, by adopting a survey of fifty undergraduates who participated in the programme from 1998 to 2003. Among the students, 31 research projects were completed resulting in 18 peer-reviewed, scientific publications, 15 oral and 28 poster presentations at scientific meetings and greater than 120 presentations to lay organizations. The students who participated in the undergraduate research 
mentoring programme had a mean 0.5 grade point improvement from their junior year to graduation compared with students in the control group. In addition, more undergraduate research mentoring programme students graduated with a B.S degree and also graduated sooner, obtained employment within the wildlife profession soon$\mathrm{er}$, and had greater success in obtaining wildlife-related employment than students of the control group. The undergraduate research mentoring programme was perceived by participants as a positive influence in their academic career, which taught them to focus on their goals and made them more marketable for employment after graduation.

Poor supervision can have significant impacts on supervisees, not only limiting the quality of their work, but also their motivation. These challenges that influence the way supervisees carry out their research projects are grouped into three. They are the supervisor-related, supervisee-related and institution-related challenges. Research authorities of the likes of Shumba [2004], Nyawaranda [2005], Pearce [2005] and Chabaya et al. [2009] listed the following as some of the supervisor-related challenges in the supervision of supervisees research projects: too few meetings with students; failure to return work promptly; lack of research experience; no interest in the topic; too little practical help given; absence from department leaving no co-supervisor; lack of relevant skills or knowledge; failure to return work promptly; lack of motivating factors; too little direction; and no interest in the students.

Pearce [2005] and Anderson et al. [2006] proved that lack of library resources; students failure to meet regularly with the supervisor; family problems/commitments; lack of time; lack of adequate theory in the area being researched; lack of money; lack of commitment and motivation to carry out the research; and imposition of research topics on supervisees all have a negative influence on supervisees' success in research work [Thondhlana et al., 2011]. The scholars were of the opinion that an ability to handle both supervisor-related and supervisee-related challenges in research supervision are a pre-condition to the quality of research projects produced by both the supervisor and supervisee.

\section{Materials and methods}

This study examined the comparative studies of research project supervision on student graduating performance. Hence, a study of university of Ilorin and Kwara State University was used to gain access to the required information, from which a judgmental sample of the two universities was adopted to verify the stated hypotheses. The philosophy of research adopted in this study was epistemology (realism) and the philosophy of research approach was pragmatism, as this is seen by some scholars as providing an epistemological justification for the mixed approach. In the same vein, this study considered the survey method and descriptive design complemented by the case study method. The survey method was adopted in this study because it tends to be the most appropriate method when participants opinions are sought 
[Punch, 2004] as cited in the work of Tichaona and Onias [2011]. Furthermore, the case study was adopted because it is used to describe an intervention or phenomenon and the real context in which it occurred [Yin, 2003].

The population of the study was structured into graduated (who comprise the lecturers and non- lecturing staff excluding associate lecturers) and the graduating students, which constitute the current 400 level students of Kwara State University and University of Ilorin as the population. The questionnaires were structured on a five-point Likert scale in the order of 5 for "strongly agree", 4 for "agree", 3 for "undecided", 2 for "disagree" and 1 for "strongly disagree", and addressed the lecturers as supervisors. The study used the Spearman correlation to assess the relationship that existed among the variables specified in the questionnaire and data analyses of the two universities were depicted separately on the same table to show the comparison of outcomes without bias. Furthermore, questionnaires were designed to address the current graduating students as supervisees. The information gathered and obtained from the graduating students was compared in both institutions. The population is tabulated below.

Table 1. Population of selected universities staff and graduating students

\begin{tabular}{|l|c|c|}
\hline \multicolumn{1}{|c|}{ Universities } & Staff with graduated status (SWGS) & No. of students currently graduating (NSCG) \\
\hline KWASU & 47 & 680 \\
\hline UNILORIN & 55 & 1,000 \\
\hline
\end{tabular}

Source: Field survey [2017].

Therefore, in this study we determined the sample size by adopting the Yaro Yamanne formula and the continuous and categorical table. The reason for choosing the Yards formula is because it is concerned with the application of a normal approximation of $95 \%$ confidence level and $5 \%$ error tolerance. The formula is given as follows:

$$
\mathrm{n}=\frac{\mathrm{N}}{1+\alpha^{2} \mathrm{~N}}
$$

Where:

$\mathrm{n}=$ sample size,

$\mathrm{N}=$ population,

$\alpha=$ level of significance/error tolerance.

Therefore, substituting the number below:

$\mathrm{n}=\mathrm{KWASU}$ SWGS, $\mathrm{N}=47, \alpha=0.05$

$\mathrm{n}=\frac{47}{1+0.05^{2}(47)}=\frac{47}{1.1175}=42$ respondents

$\mathrm{n}=$ UNILORIN SWGS, $\mathrm{N}=55, \alpha=0.05$ 
Pobrane z czasopisma Annales H - Oeconomia http://oeconomia.annales.umcs.pl Data: 26/04/2023 15:03:53

$$
\begin{aligned}
& \mathrm{n}=\frac{55}{1+0.05^{2}(55)}=\frac{55}{1.1375}=48 \text { respondents } \\
& \mathrm{n}=\text { KWASU NSCG, N }=680, \alpha=0.05 \\
& \mathrm{n}=\frac{680}{1+0.05^{2}(680)}=\frac{680}{2.7}=252 \text { respondents } \\
& \mathrm{n}=\text { UNILORIN NSCG, N }=1,000, \alpha=0.05 \\
& \mathrm{n}=\frac{1,000}{1+0.05^{2}(1,000)}=\frac{1,000}{3.5}=286 \text { respondents }
\end{aligned}
$$

Total KWASU Sample is $42+252=294$, while UNILORIN sample is $48+286=334$.

Note: SWGS represents staff with graduating status and NSCG represents the number of student currently graduating.

\section{Interpretation of results}

Table 2. Universities respondents rate analysis

\begin{tabular}{|l|l|r|r|r|c|}
\hline \multirow{2}{*}{ Questionnaire } & \multicolumn{1}{|c|}{ Structure } & \multicolumn{2}{c|}{ Frequency } & \multicolumn{2}{c|}{ Percentage } \\
\cline { 3 - 6 } & & KWASU & UNILORIN & KWASU & UNILORIN \\
\hline \multirow{4}{*}{ Administered } & Graduating students & 252 & 286 & $86 \%$ & $86 \%$ \\
\cline { 2 - 6 } & Lecturers & 42 & 48 & $14 \%$ & $14 \%$ \\
\cline { 2 - 6 } & Total & 294 & 334 & $100 \%$ & $100 \%$ \\
\hline \multirow{4}{*}{ Returned } & Graduating students & 241 & 236 & $90 \%$ & $88 \%$ \\
\cline { 2 - 6 } & Lecturers & 26 & 33 & $10 \%$ & $12 \%$ \\
\cline { 2 - 6 } & Total & 267 & 269 & $100 \%$ & $100 \%$ \\
\hline \multirow{2}{*}{$\begin{array}{l}\text { Unreturned } \\
\text { rate (N) }\end{array}$} & Total not filled & 47 & 44 & $18 \%$ & $16 \%$ \\
\hline \multirow{3}{*}{ Not returned } & Total filled & 220 & 225 & $82 \%$ & $84 \%$ \\
\hline & Graduating students & 11 & 50 & $41 \%$ & $77 \%$ \\
\cline { 2 - 6 } & Lecturers & 16 & 15 & $59 \%$ & $23 \%$ \\
\cline { 2 - 6 } & Total & 27 & 65 & 100 & $100 \%$ \\
\hline
\end{tabular}

Source: Field survey [2017].

In this study, 294 copies of questionnaire were distributed in KWASU, and 334 copies in UNILORIN for both lecturers and current graduating students, and 267 and 269 were returned respectively in KWASU and UNILORIN. Of the 267 copies of questionnaire returned in KWASU, 220 were filled, 29 were wrongly filled and 18 were not filled, while in UNILORIN, of the 269 copies of questionnaire returned, 225 were filled and 44 were not filled.

Hence, 27 copies of the questionnaire were not returned in KWASU and 65 were also not returned in UNILORIN. The administered questionnaires, returned 
questionnaires and the questionnaires not returned are analysed in the table above. It should be noted that some of the returned questionnaires were not properly filled, some of the respondents did not fill the questionnaire at all and such questionnaires were disregarded for the purpose of analysis. For the sake of analysis, we considered the questionnaires that were properly filled.

Table 3. Frequency distribution of graduating student demographic characteristics

\begin{tabular}{|c|c|c|c|c|}
\hline Characteristics & KWASU & & UNILORIN & Percentage \\
\hline Age & Frequency & Percentage & Frequency & $53.8 \%$ \\
\hline $18-22$ & 123 & $55.9 \%$ & 121 & $37.3 \%$ \\
\hline $23-27$ & 84 & $38.2 \%$ & 84 & $5.3 \%$ \\
\hline $28-32$ & 11 & $5 \%$ & 5 & $2.2 \%$ \\
\hline $33-37$ & 1 & $0.5 \%$ & 3 & $1.3 \%$ \\
\hline 38 and above & 1 & $0.5 \%$ & 225 & $100 \%$ \\
\hline Total & 220 & $100 \%$ & Frequency & Percentage \\
\hline Gender & Frequency & Percentage & 105 & $46.7 \%$ \\
\hline Male & 122 & $55.5 \%$ & 120 & $53.3 \%$ \\
\hline Female & 98 & $44.5 \%$ & 225 & $100 \%$ \\
\hline Total & 220 & $100 \%$ & Frequency & Percentage \\
\hline Marital status & Frequency & Percentage & 195 & $86.7 \%$ \\
\hline Single & 210 & $95.5 \%$ & 29 & $12.9 \%$ \\
\hline Married & 10 & $4.5 \%$ & 1 & $0.4 \%$ \\
\hline Divorced & 0 & 0 & 225 & $100 \%$ \\
\hline Total & 220 & $100 \%$ & Frequency & Percentage \\
\hline Religion & Frequency & Percentage & 127 & $56.4 \%$ \\
\hline Christianity & 90 & $40.9 \%$ & 94 & $41.8 \%$ \\
\hline Islam & 130 & $59.1 \%$ & 4 & $1.8 \%$ \\
\hline Traditional & 0 & 0 & 225 & $100 \%$ \\
\hline Total & 220 & $100 \%$ & & \\
\hline
\end{tabular}

Source: Field survey [2017].

The table above illustrates that the highest percentage of respondents, approximately $56 \%$ in KWASU and 54\% in UNILORIN, respectively, were aged between 18-22 years, and the least number of respondents, almost $1 \%$ each, were aged between 33-37 years and 38 and above. It also illustrates that out of the total of 220 and 225 respondents in KWASU and UNILORIN respectively, $56 \%$ were male in the former, while $47 \%$ were male in the latter. In terms of female respondents, the figures were approximately $45 \%$ and $53 \%$ for KWASU and UNILORIN respectively. This was because the male respondents were more cooperative than their female counterparts in KWASU, while in UNILORIN the reverse is the case. The table further indicates that approximately $96 \%$ and $87 \%$ were single, and approximately $5 \%$ and $13 \%$ married, in KWASU and UNILORIN respectively. Less than $1 \%$ were divorced in UNILORIN, while none were in KWASU. Approximately $56 \%$ and $41 \%$ of the respondents were Christians, and approximately $59 \%$ and $42 \%$ were Muslims, in KWASU and UNILORIN respectively. Approximately $2 \%$ were traditional worshippers in UNILORIN. 
Pobrane z czasopisma Annales H - Oeconomia http://oeconomia.annales.umcs.pl

Data: 26/04/2023 15:03:53

AKINBOLA OLUFEMI AMOS et al.

Table 4. The descriptive statistics of project supervision and graduating students performance

\begin{tabular}{|c|c|c|c|}
\hline & Questions (Supervisors) & $\begin{array}{c}\text { KWASU } \\
(\mathrm{N}=220) \\
\text { Mean }\end{array}$ & $\begin{array}{l}\text { UNILORIN } \\
(\mathrm{N}=225) \\
\text { Mean }\end{array}$ \\
\hline 1 & $\begin{array}{l}\text { I am motivated by the ability of my supervisees in the crafting of researchable } \\
\text { topics and this aids their writing and research capacity }\end{array}$ & 3.23 & 3.41 \\
\hline 2 & $\begin{array}{l}\text { Supervisees are always committed in carrying out a quality and original re- } \\
\text { search project, thereby improving their writing and research capacity }\end{array}$ & 3.45 & 3.21 \\
\hline 3 & $\begin{array}{l}\text { I am motivated when my supervisees comply with the instructions I give to } \\
\text { them and this has a positive impact on their writing and research capacity }\end{array}$ & 4.11 & 3.47 \\
\hline 4 & I guide my supervisees on how to effectively manage their time & 3.89 & 3.32 \\
\hline 5 & $\begin{array}{l}\text { Supervisees are being encouraged to complete their research project within the } \\
\text { stipulated time }\end{array}$ & 3.56 & 3.21 \\
\hline 6 & $\begin{array}{l}\text { I contribute to the originality of my supervisee's research project by adding my } \\
\text { knowledge and experience to the research project of my supervisee within the } \\
\text { time frame }\end{array}$ & 3.42 & 3.22 \\
\hline 7 & $\begin{array}{l}\text { My supervisees are not financially buoyant and this have a negative effect on } \\
\text { the quality of their exposure in regards to researching }\end{array}$ & 3.89 & 4.11 \\
\hline 8 & $\begin{array}{l}\text { Supervisees are not always punctual in returning their research project and this } \\
\text { in turn has a negative impact on their exposure to research }\end{array}$ & 3.41 & 4.14 \\
\hline 9 & Supervisees are poor at project writing and researching & 3.43 & 3.88 \\
\hline \multirow[t]{2}{*}{10} & Supervisees lack adequate theory in the area in which they are researching & 3.91 & 3.76 \\
\hline & Questions (Supervisees) & Mean & Mean \\
\hline 1 & $\begin{array}{l}\text { I was given directions by my supervisor and this positively affected the quality } \\
\text { of my writing and research capacity }\end{array}$ & 3.66 & 3.63 \\
\hline 2 & $\begin{array}{l}\text { I had access to Internet facilities and this aided my writing and research capac- } \\
\text { ity }\end{array}$ & 3.47 & 3.67 \\
\hline 3 & $\begin{array}{l}\text { I was privileged to get the required and relevant materials needed to carry out } \\
\text { my research project thereby improved my writing and research capacity }\end{array}$ & 3.69 & 3.44 \\
\hline 4 & I was unable to complete my research project within the stipulated time & 3.34 & 3.65 \\
\hline 5 & My supervisor did not guide me on how to effectively manage my time & 2.32 & 2.12 \\
\hline 6 & $\begin{array}{l}\text { I was responsible for the original contribution and pursuance of my research } \\
\text { project to completion }\end{array}$ & 2.14 & 2.10 \\
\hline 7 & $\begin{array}{l}\text { Effective management of my time aids my performances in carrying out my } \\
\text { research project }\end{array}$ & 2.31 & 2.22 \\
\hline 8 & $\begin{array}{l}\text { I experienced financial constraints when I was carrying out my research project } \\
\text { and this negatively affected my exposure to research }\end{array}$ & 3.84 & 3.91 \\
\hline 9 & $\begin{array}{l}\text { Crafting of researchable topics was a big task for me and this led to a negative } \\
\text { impact on my exposure in regards to research }\end{array}$ & 3.92 & 3.94 \\
\hline 10 & $\begin{array}{l}\text { Supervisors engage in other school activities which leads to the failure to return } \\
\text { the supervisee's research project promptly }\end{array}$ & 1.51 & 1.32 \\
\hline 11 & $\begin{array}{l}\text { Most supervisors are likely to supervise students the same way they themselves } \\
\text { were supervised }\end{array}$ & 4.14 & 4.12 \\
\hline 12 & $\begin{array}{l}\text { Differences in supervisors affect supervisees in their writing and research } \\
\text { capacity }\end{array}$ & 4.22 & 3.91 \\
\hline
\end{tabular}

Source: Author's fieldwork computation [2017]. 
Pobrane z czasopisma Annales H - Oeconomia http://oeconomia.annales.umcs.pl Data: 26/04/2023 15:03:53

COMPARATIVE STUDY OF RESEARCH PROJECT SUPERVISION ON THE PERFORMANCE...

Table 5. Descriptive mean statistics of the respondents based on variable questions

\begin{tabular}{|l|c|c|c|c|c|}
\hline Mean of variables & $\mathrm{N}$ & Minimum & Maximum & Mean & Std. deviation \\
\hline Motivational factors & 445 & 2 & 4 & 3.35 & 0.689 \\
\hline Time management & 445 & 1 & 4 & 3.62 & 0.696 \\
\hline Inhibiting factors & 445 & 2 & 4 & 3.23 & 0.655 \\
\hline Research capacity & 445 & 1 & 5 & 3.51 & 0.671 \\
\hline
\end{tabular}

Source: Author's fieldwork computation [2017].

Table 5 illustrates the degree of mean of respondents based on the agreement of respondents in relation to the variables. Time management has the highest mean value of 3.62, while research capacity is next with a mean of 3.51 and motivational factors have a mean of 3.35 , while inhibiting factors have a mean of 3.23 , depicting the level of responses to the variables as described in the questionnaire instrument.

\section{Test of hypotheses}

\section{Research Hypothesis One}

H1: There is no relationship between the research project motivational factor and student writing and research capacity.

Table 6. Research project motivational factor (RPMF)

\begin{tabular}{|c|c|c|c|c|c|c|c|}
\hline & \multicolumn{2}{|c|}{ RPMF } & \multicolumn{2}{|c|}{ RPMF } & \multicolumn{2}{|c|}{ RPMF } \\
\hline & & KWASU & UNILORIN & KWASU & UNILORIN & KWASU & UNILORIN \\
\hline \multirow{3}{*}{ RPMF } & $\begin{array}{l}\text { Spearman } \\
\text { correlation }\end{array}$ & & & $0.182 * *$ & $0.137 *$ & $0.195 * *$ & $0.264 * *$ \\
\hline & Sig. (2-tailed) & & & 0.005 & 0.022 & 0.002 & 0.000 \\
\hline & $\mathrm{N}$ & & & 220 & 225 & 220 & 225 \\
\hline \multirow{3}{*}{ RPMF } & $\begin{array}{l}\text { Spearman } \\
\text { correlation }\end{array}$ & $0.182 * *$ & $0.137 *$ & & & $0.386 * *$ & $0.239 * *$ \\
\hline & Sig. (2-tailed) & 0.005 & 0.022 & & & 0.000 & 0.000 \\
\hline & $\mathrm{N}$ & 220 & 225 & & & 220 & 225 \\
\hline \multirow{3}{*}{ RPMF } & $\begin{array}{l}\text { Spearman } \\
\text { correlation }\end{array}$ & $0.195 * *$ & $0.264 * *$ & $0.386^{* *}$ & $0.239 * *$ & & \\
\hline & Sig. (2-tailed) & 0.002 & 0.000 & 0.000 & 0.000 & & \\
\hline & $\mathrm{N}$ & 220 & 225 & 220 & 225 & & \\
\hline
\end{tabular}

Source: Field survey [2017].

RPMF - Research Project Motivational Factor

* correlation is significant at the 0.05 level (2-tailed).

** correlation is significant at the 0.01 level (2-tailed). 


\section{Interpretation of results}

The study measured the items of research project motivational factors, and student writing and research capacity and the Spearman correlation coefficient $r$ gave a significance or $p$-value of less than 0.01 in both universities and 0.05 in UNILORIN, which is less than alpha 0.01 and 0.05 as shown in the table above. This study reveals that there is a relationship between research project motivational factors and student writing and research capacity. Hence, hypothesis 1 as stated above is rejected.

\section{Research Hypothesis Two}

$\mathrm{H} 2$ : Inhibiting factors in project writing do not correlate to student exposure to research.

Table 7. Inhibiting factors in project writing (IFIPW)

\begin{tabular}{|c|c|c|c|c|c|}
\hline & \multicolumn{2}{|c|}{ IFIPW } & \multicolumn{2}{|c|}{ IFIPW } \\
\hline & & KWASU & UNILORIN & KWASU & UNILORIN \\
\hline \multirow{3}{*}{ IFIPW } & Spearman correlation & & & $0.185^{* *}$ & $0.422 * *$ \\
\hline & Sig. (2-tailed) & & & 0.005 & 0.000 \\
\hline & $\mathrm{N}$ & & & 220 & 225 \\
\hline \multirow{3}{*}{ IFIPW } & Spearman correlation & $0.185^{* *}$ & $0.422 * *$ & & \\
\hline & \begin{tabular}{|l|} 
Sig. (2-tailed) \\
\end{tabular} & 0.005 & 0.000 & & \\
\hline & $\mathrm{N}$ & 220 & 225 & & \\
\hline
\end{tabular}

Source: Field survey [2017].

IFIPW - Inhibiting Factors in Project Writing

** correlation is significant at the 0.01 level (2-tailed).

\section{Interpretation of results}

The study measured the items of inhibiting factors in project writing and student exposure to research and the Spearman correlation coefficient $r$ gave a significance or $p$-value of 0.000 and 0.005 in both universities, which is less than alpha 0.01 as shown in the table above. This study reveals that there is relationship between inhibiting factors in project writing and student exposure to research. Hence, hypothesis 2 as stated above is rejected.

\section{Research Hypothesis Three}

H3: The relationship between inhibiting factors in project writing, student writing and research capacity is insignificant. 
Pobrane z czasopisma Annales H - Oeconomia http://oeconomia.annales.umcs.pl Data: 26/04/2023 15:03:53

COMPARATIVE STUDY OF RESEARCH PROJECT SUPERVISION ON THE PERFORMANCE...

Table 8. Student writing and research capacity (SWARC)

\begin{tabular}{|c|c|c|c|c|c|c|c|}
\hline & \multicolumn{2}{|c|}{ SWARC } & \multicolumn{2}{|c|}{ SWARC } & \multicolumn{2}{|c|}{ SWARC } \\
\hline & & KWASU & UNILORIN & KWASU & UNILORIN & KWASU & UNILORIN \\
\hline \multirow{3}{*}{ SWARC } & $\begin{array}{l}\text { Spearman } \\
\text { correlation }\end{array}$ & & & $0.252^{* *}$ & $0.452 * *$ & $0.179^{* *}$ & $0.439 * *$ \\
\hline & Sig. (2-tailed) & & & 0.000 & 0.000 & 0.005 & 0.000 \\
\hline & $\mathrm{N}$ & & & 220 & 225 & 220 & 225 \\
\hline \multirow{3}{*}{ SWARC } & $\begin{array}{l}\text { Spearman } \\
\text { correlation }\end{array}$ & $0.252 * *$ & $0.452 * *$ & & & $0.239 * *$ & $0.502 * *$ \\
\hline & \begin{tabular}{|l} 
Sig. (2-tailed) \\
\end{tabular} & 0.000 & 0.000 & & & 0.000 & 0.000 \\
\hline & $\mathrm{N}$ & 220 & 225 & & & 220 & 225 \\
\hline \multirow{3}{*}{ SWARC } & $\begin{array}{l}\text { Spearman } \\
\text { correlation }\end{array}$ & $0.179 * *$ & $0.439 * *$ & $0.239^{* *}$ & $0.502 * *$ & & \\
\hline & Sig. (2-tailed) & 0.006 & 0.000 & 0.000 & 0.000 & & \\
\hline & $\mathrm{N}$ & 220 & 225 & 220 & 225 & & \\
\hline
\end{tabular}

Source: Field survey [2017].

SWARC - Student Writing and Research Capacity

** correlation is significant at the 0.01 level (2-tailed).

\section{Interpretation of results}

The study measured the items of inhibiting factors in project writing, student writing and research capacity and the Spearman correlation coefficient $r$ gave a significance or $p$-value of 0.000 in both universities and 0.005 in KWASU, which is less than alpha 0.01 as shown in the table above. This study reveals that there is a relationship between inhibiting factors in project writing, student writing and research capacity. Hence, hypothesis 3 as stated above is rejected.

\section{Discussion of findings}

With three hypotheses tested to check the effect of independent variables on dependent variables, the findings of the study on research project writing reveal that motivational factors and inhibiting factors affect student graduating performance.

The results indicate that research project motivational factors have a positive impact on student writing and research capacity. They also suggest that there is a positive relationship between research project motivational factors and student time management. Research scholars of the likes of Tichaona and Onias [2011] have made significant contributions to corroborate the above-stated evidence that students approaching their final year in university need considerable encouragement and motivation to have interest in research writing and not see it as an unattainable task, because most students usually have a phobia of conducting research independently to avoid mistakes in writing.

In the same vein, the evidence shows that inhibiting factors in research project writing have a negative impact on student exposure to research. It also shows that inhibiting factors in project writing negatively affect student writing and research 
capacity. Research authorities in the mould of Shumba [2004], Nyawaranda [2005], Pearce [2005] and Chabaya et al. [2009] also made significant contributions to support the above-stated evidence that inhibiting factors such as the inability to cooperate with supervisors and individual differences of project supervision styles do affect students negatively. Furthermore, the issues of not letting students write projects in their own area of interest should be discouraged, even though it has been the contention of supervisors that most students do not like to write an original research project that is novel and creative in nature.

Finally, based on the tested hypotheses of the lecturers' opinions, the results show that lecturers in Kwara State University are motivated when their supervisees complete their research project within the stipulated time, while in the University of Ilorin the reverse is the case. Furthermore, there is evidence from lecturers' opinions in both universities that when their supervisees are not financially buoyant, it negatively affects their project writing and research capacity, delivery and sometimes submission deadlines, as most students are dependent on family financial support.

\section{Conclusions}

The present study sought to compare research project supervision on student graduating performance at the Faculty of Management Sciences and Social sciences in UNILORIN and the School of Business and Governance in KWASU with particular reference to six departments in the two universities. The study covers the period of the 2014/2015 academic session in the two universities. In the selected universities, completing a research project is core and critical at the graduating level. A research project allows the students to apply their knowledge and concept acquired in their study while enhancing their research skills through the scope and depth of their inquiry.

In the same vein, supervisors who supervise the students have different methodological inclinations, research backgrounds, expertise and experience, and, as such most supervisors are likely to supervise students the same way they themselves were supervised. Based on the findings, it is evident that research project motivational factors have a positive impact on student writing and research capacity and student time management, while inhibiting factors in project writing have a negative impact on student exposure to research and student writing and research capacity. Therefore, when research project motivational factors are given to students and their supervisors, they in turn have a positive impact on the student writing and research capacity, exposure to research and student time management. 


\section{Recommendations}

Based on the outcomes of the study, it is recommended that:

1. Students and their supervisors should be encouraged to carry out research in the area of research project supervision, writing and defence.

2. Research workshops and seminars on different aspects of research should be conducted by the two universities for both lecturers and students. The research workshop will be a means of impacting research skills on the students and lectures, while the seminars could be used as an opportunity for the students and lecturers to present the different aspects of the research to their supervisors and colleagues respectively, for the purpose of criticizing them on a non-threatening platform.

3. We recommend that supervisors who have their own methodological inclination should have a working knowledge of both qualitative and quantitative research methods.

4. Students should be guided on how to effectively manage their time with regards to writing quality and their original research project.

5. Supervisors can perfect student research skills at the same time as transferring their research skills to their students by actively engaging in research-related activities in which they can collaborate with their students.

6. A system model of research supervision with set stages and monitoring should be considered by both universities.

7. At the initial stages of research supervision, we recommend that supervisors discuss with their students their expectations as well as the effort and commitment required in order to produce an original and high quality research project.

8. Supervisors can also google topics brought to them by those under their supervision, to find out whether or not suggested topics have been done elsewhere.

9. Students should be encouraged to give colleagues their research work for peer review before handing it to their supervisors.

\section{Contributions to knowledge}

This research has contributed to knowledge in the following ways:

1. Most of the scholars in this line of study have concentrated more on post graduate students, but in this study we have contributed to knowledge by focusing on undergraduates. In conjunction, this study has compared research project supervision in the two universities while most of the research work in this area of study has concentrated only on a study.

2. Finally, this study has also examined research project supervision from two different perspectives, which include those of the supervisors and graduating 
students, unlike other research work carried out in this line of study where most researchers concentrated more on only one perspective - either that of students or supervisors.

\section{References}

Ali, S., Zubair, H., Fahad, M., Hamid, K., Awais, A., Factors contributing to the students academic performance: A case study of Islamia University Sub-Campus, "American Journal of Educational Research" 2013, Vol. 1(8), pp. 283-289. DOI: 10.12691/education-1-8-3.

Ali, N., Jusoff, K., Ali, S., Mokhtar, N., Salamt, A., The factors influencing students 'performance at Universiti Teknologi MARA Kedah, Malaysia, "Canadian Research \& Development Center of Sciences and Cultures" 2009, Vol. 3(4), pp. 1-7.

Anderson, C., Day, K., MacLaughlin, P., Mastering the dissertation: Lecturers' representations of the purposes and processes at master level dissertation supervision, "Studies in Higher Education" 2006, Vol. 31(2), pp. 20-31. DOI: 10.1080/03075070600572017.

Bell, J., Doing Your Research Project, Open University Press, Buckingham 2000.

Cambridge University Reporter, Indicators of Academic Performance, 2003, http://www.admin.cam.ac.uk/ reporter/2002-3/weekly/5913 [access: 8.08.2007].

Chabaya, O., Chiome, C., Chabaya, R.A., Students'failure to submit research projects on time: A case study from Masvingo Regional Centre at Zimbabwe Open University, “Open Learning” 2009, Vol. 24(3), pp. 211-221. DOI: 10.1080/02680510903201615.

Doreen, H.K, Scott, E.H., Impact of undergraduate research on academic performance, educational planning, and career development, "Journal of Natural Resource Life Science Education" 2006, Vol. 35(1), pp. 194-201. DOI: 10.2134/jnrlse2006.0194.

Dundalk Institute of Technology. Project Supervision Guidelines for Staff and Students, Centre for Excellence in Learning and Teaching, 2011, https://www.dkit.ie [access: 9.12.2013].

Frischer, J., Larsson, K., Laissez-faire in research education - an inquiry into a Swedish doctoral program, "High Education Policy" 2000, Vol. 13(2), pp. 132-155. DOI: 10.1016/S0952-8733(99)00022-7.

Grant, B.M., Fighting for space in supervision: Fantasies, fairytales, fictions and fallacies, "International Journal of Qualitative Studies in Education” 2005, Vol. 18(3), pp. 337-354.

DOI: $10.1080 / 09518390500082483$.

Herzberg, F., The motivation-hygiene concept and problems of manpower, "Personnel Administration" 1964, Vol. 27(1), pp. 3-7. DOI: 10.1111/j.1744-6570.1971.tb02470.x/pdf.

Hunter, A.B., Laursen, S.L, Seymour, E., Becoming a scientist: The role of undergraduate research in students cognitive, personal, and professional development, "Science Education" 2006, Vol. 91(1), pp. 36-74. DOI: 10.1002/sce.20173.

Jeremy, C.B., Supervision Models and Theories. Small Business. Demand Media, 2014, https://smallbusiness.chron.com/supervision-models-theories-61052.html [access: 9.11.2016].

Lee, A., How can a mentor support experimental learning?, "Journal of Clinical Child Psychology and Psychiatry" 2007, Vol. 12(13), pp. 333-340. DOI: 10.1177/1359104507078455.

Nyawaranda, V.A., Supervising research projects/dissertations, a paper delivered at the Zimbabwe Open University (ZOU) workshop, Mashonaland Central Region, Bindura 2005.

Narayana, R.K.V.S.S., Ph. D. Research Supervision: Some thoughts. A knoll. Delhi School of Economics, Delhi 2009.

Pearce, L., How to Examine a Thesis, Society for Research into Higher Education and Open University, United Kingdom 2005. 
Shumba, O., The social research workshops, quantitative educational research: Synopsis and reflections on the scope of data analysis, 2004, files.eric.ed.gov/fulltext/EJ983622.pdf

Punch, K.F., Introduction to Social Research Quantitative and Qualitative Approaches SAGE Publications, London 2004.

Sidhu, K.S., Methodology of Research in Education, Sterling, New Delhi 2001.

Tichaona, M., Onias, M., Challenges being experienced by undergraduate students in conducting research in open and distance learning, "International Journal of Asian Social Science" 2011, Vol. 2(10), pp. 94-106.

Thondhlana, S., Mawere, D., Weda, Z., Factors affecting completion of research projects by students: a study of three Zimbabwe Open University regions, "Zimbabwe International Journal of Open \& Distance Learning" 2011,Vol. 1(1), pp. 112-129.

Vergara, S.C., Gestão de Pessoas, Atlas, Sao Paulo 2000.

Wisker, G., The Good Supervisor, Palgrave Macmillan, Basingstoke 2005.

Yin, R.K., Case Study Research: Design and Methods, (3 $3^{\text {rd }}$ ed.), SAGE Publications, Thousand Oaks 2003.

\section{Analiza porównawcza nadzoru nad projektem badawczym w zakresie osiągnięć studentów biznesu na uniwersytetach nigeryjskich}

Badanie miało na celu porównanie nadzoru nad projektem badawczym wśród studentów kończących studia w Kwara State University (KWASU) i University of Ilorin (UNILORIN) przez dwie sesje. Nacisk położono na ustalenie związku między czynnikami motywacyjnymi, czynnikami hamującymi, pracą uczniów i możliwościami badawczymi. W badaniu wykorzystano projekt korelacji do ustalenia charakteru relacji. Ujawniono istnienie istotnego związku między wyżej wymienionymi czynnikami a zarządzaniem czasem przez studentów na obu uniwersytetach.

\section{Comparative Study of Research Project Supervision on the Performance of Graduating Business Students in Nigerian Universities}

This study was designed to compare research project supervision on Student graduating performance in Kwara State University (KWASU) and University of Ilorin (UNILORIN) for two sessions. Emphasis was put on establishing the relationship between motivational factors, inhibiting factors, student writing and research capacity. The study employed the use of correlation design to establish the nature of relationships. The findings revealed the existence of significant relationship between the above-mentioned elements and student time management in both universities. 